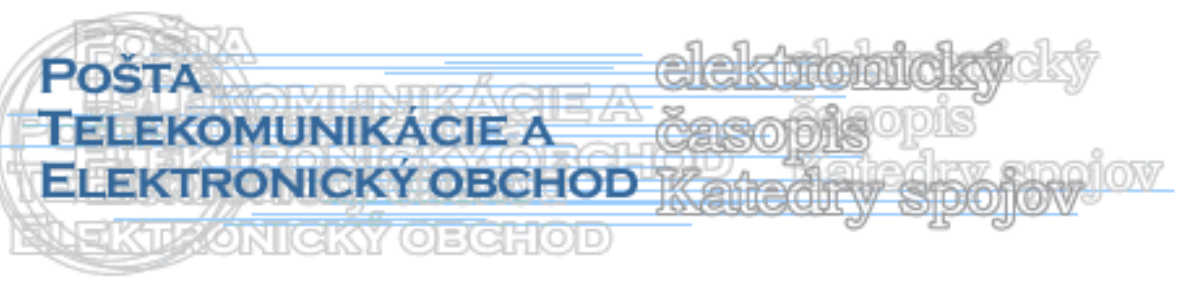

\title{
ZOBRAZENIE NÁKLADOV V NÁKLADOVOM CONTROLLINGU PROSTREDNÍCTVOM ÚČTOVNÍCTVA
}

\author{
Lucia Krátka *
}

\section{Úvod}

Úlohou controllingu je vybudovat' nákladový a kalkulačný systém informácií o štruktúre nákladov podl'a miesta a príčin vzniku vnútri podniku. Jeho hlavnou úlohou je napomáhat' riadenie zisku.

Úlohou nákladového controllingu je zvýšit' prehl'adnost' vzniku nákladov vo všetkých oblastiach podnikovej činnosti, zdokonalit' plánovanie a rozhodovanie na základe zodpovedajúcich informácií o nákladoch a využití kapacít podniku a neustále zdokonalovanie systemu podniku.

Podniky ako samostatné jednotky uskutočňujú svoju činnost' ako zložitý systém v komplikovanom usporiadaní, od elementárnych operácií až po vzt'ahy k externým subjektom vrátane rozdelenia komplexného výsledku hospodárenia.

Spôsob vynakladania nákladov na dosiahnutie kladného (záporného) výsledku hospodárenia každého podniku nám zobrazuje system účtovníctva.

\section{Zobrazenie nákladov prostredníctvom manažérskeho, finančného, daňového a nákladového účtovníctva}

Jednou zo základných myšlienok je potreba diferencovat' spôsob zobrazenia podnikatel'ského procesu podl'a toho, kto je používatel'om účtovných informácií a aké rozhodovacie úlohy rieši. Postupne tak dochádza $\mathrm{k}$ tomu, že podstatnou črtou účtovníctva vyspelých trhových ekonomík je obsahové delenie [1]:

- účtovných informácií finančného účtovníctva, ktorého ciel’om je zobrazit' podnikatel'ský proces z hl'adiska vyjadrenia informačných potrieb tzv. externých užívatel'ov,

- účtovných informácií tzv. daňového účtovníctva, ktorého zmyslom je zobrazit ten istý process primárne s ohl'adom na správne vyjadrenie základu dane z príjmu, resp. ostatných daňových pohl'adávok a záväzkov podniku,

\footnotetext{
* Ing. Lucia Krátka, Žilinská univerzita v Žiline, Fakulta prevádzky a ekonomiky dopravy a spojov, Katedra spojov, Univerzitná 1, 01026 Žilina, e-mail: kratka@fpedas.utc.sk
} 
- účtovných informácií, ktoré využívajú pre riadenie podnikatel'ských procesov pracovníci na rôznych stupňoch podnikového vedenia.

\section{Charakteristiky zobrazenia nákladov}

Prvá charakteristika nám zobrazuje transformáciu nákladov (vstupov) na výkony (výstupy) pomocou finančného a nákladového účtovníctva a jeho následného pretvorenia do manažérskeho účtovníctva.

Nákladové účtovníctvo je z tohto pohl'adu chápané najmä z dvoch aspektov [2]:

- predmet zobrazenia prvého aspektu sa zameriava na ekonomickú realitu z hl'adiska nákladov (odvodene aj výnosov a výsledku hospodárenia)

- druhý aspekt sa zaoberá rozhodovacím procesom, ktorý sa zameriava najmä na účelový popis reprodukčného procesu, ktorého určitý variant už bol prijatý. Úlohou nákladového účtovnícva je poskytovat' informácie o skutočnom a predpokladanom vývoji tohto prijatého variantu.

Druhá charakteristika nám zobrazuje časový rozdiel vynakladania nákladov. Náklad z hl'adiska manažérskeho účtovníctva sa prejaví už v momente vynaloženia ekonomického zdroja. Toto vynaloženie väčšinou nevedie k celkovému úbytku majetku, ale len k zmene v jeho štruktúre.

Náklad z hl'adiska finančného účtovníctva sa prejaví až v momente, ked' tento zdroj vyčerpá svoju užitočnost', napriklad tým že sa stane súčast'ou výrobku, ktorý sa predal zákazníkovi.

Zvláštnou formou vzájomného vzt’ahu obidvoch týchto chápaní časového rozdielu vynakladania nákladov je zobrazenie výrobnej činnosti alebo vytváranie iných aktív vo vlastnej réžii.

Náklady vynaložené v súvislosti s touto činnost'ou môžeme rozdelit' na:

- tie, ktorých vynaloženie je vyjadrené ako zvýšenie budúceho ekonomického prospechu vytváraného aktíva. Tieto náklady sa aktivujú v ocenení tohto aktíva a až do momentu jeho predaja sa vykazujú ako náklady produktu.

- tie, ktorých vynaloženie je chápané ako vyčerpanie ekonomického úžitku, ktorý tento zdroj v sebe obsahoval a ktoré sa teda už v hodnotenom období prejavia úbytkom aktív alebo prírastkom firemných záväzkov súvzt’ažne so znížením zisku bežného obdobia [2].

\section{Sledovanie nákladov podl’a útvarov v nákladovom controllingu}

Základnou charakteristikou sledovania nákladov $\mathrm{v}$ podnikových útvaroch je jeho dvojaká orientácia [2] :

○ prvým impulzom tohto členenia nákladov bola potreba zistit' náklady tak, aby z ich vzt'ahu k útvarom bolo možné odvodit’ náklady výkonov, ktoré sú predmetom činnosti útvarov. Zobrazenie takto členených nákladov sa primárne orientuje na otázku: V ktorom útvare náklad vznikol?

- Rozširujúce sa požiadavky na využitie účtovníctva v riadení, ktoré súviseli jednak so splynutím žiaducich veličín do účtovného zobrazenia, sa však postupne prejavili odklonom od sledovania nákladov podl'a miesta vzniku, 
so stale väčším dôrazom na členenie nákladov podl'a zodpovednosti za ich vznik. V súčasnosti sa teda silnejšie presadzuje tendencia koncipovat' zodpovednostné útvary, $\mathrm{v}$ ktorých sa sledovanie nákladov primárne orientuje na otázku: Ovplyvňuje útvar výšku nákladov či nie?

Konečným účelom vynaloženia nákladov sú finálne výkony, ale princíp účelovosti však prestupuje celým procesom transformácie nákladov na finálne výkony, od jednotlivých operácií až po finálny výkon.

Touto transformáciou sa prelínajú dve základné línie, ktoré treba riadit', a to:

- výkonová linia, ktorá sa orientuje na vyjadrenie vzt’ahu nákladov ku konkrétnemu výrobku, práci, službe, ale aj čiastkovým výkonom, aktivitám a činnostiam, ktoré sa uskutočňujú vo vzájomných väzbách, charakterizujúcich hlavné, pomocné a obslužné procesy,

- útvarová línia, ktorá sleduje primárnu otázku: v ktorom útvare bol náklad vynaložený, ktorý útvar zodpovedá za jeho vznik.

Komplikácie však prináša skutočnost', že zabezpečenie informácií na riadenie po línii výkonov a línii zodpovednosti útvarov nie je vždy možné a vyžaduje si to v niektorých prípadoch diferencovaný prístup.

\section{Požiadavky na výkonovo orientované účtovníctvo}

Ak je hlavným ciel'om nákladového účtovníctva zist'ovat' a kontrolovat' náklady vo vzt’ahu $\mathrm{k}$ jednotlivým finálnym výkonom, je sledovanie nákladov $\mathrm{v}$ útvaroch zamerané na miesto vynaložených nákladov. Z členenia nákladov podl’a miesta vzniku sa potom relatívne jednoducho odvodí priamy alebo nepriamy vzt'ah nákladov k výkonom alebo jeho častiam, ktoré útvar vykonáva. Tento spôsob vyhovuje potrebám riadenia nákladov po línii výkonov.

Niekedy však môže komplikovat' riadenie nákladov podl’a zodpovednosti vnútropodnikových útvarov za ich vznik, pretože to vyžaduje jednak [2] :

- rozčlenenie nákladov nie podl’a miesta vzniku, ale podl’a útvaru zodpovedajúceho za vznik,

- zúčtovat' vnútropodnikové výkony odovzdané medzi jednotlivými útvarmi na úrovni vopred stanoveného ocenenia (ocenenie na úrovni skutočných nákladov neumožňuje vyjadrit' zodpovednost' za racionálne uskutočňovanie alebo čerpanie týchto výkonov).

Pri primárnej orientácii manažérskeho účtovníctva na riadenie po línii výkonov musia byt' niektoré informácie nevyhnutné na riadenie predmetom sledovania. Systém nákladového účtovníctva sa potom orientuje na potreby sledovania skutočných nákladov uskutočňovaných výkonov. Výsledná kalkulácia sa zostaví priamo z údajov poskytnutých účtovníctvom.

\section{Požiadavky na zodpovednostne orientované účtovníctvo}

$\mathrm{Na}$ rozdiel od výkonovo orientovaného účtovníctva je jeho základom rozčlenenie nákladov podl'a zodpovednosti za ich vznik. V tomto prípade sa účtovníctvo t'ažšie sleduje. Preto výsledná kalkulácia nevzniká väzbou nákladov útvaru na jeho výkony ale úpravou nákladov jednak na presuny plynúce $\mathrm{z}$ rozdielov medzi skutočnými nákladmi a 
vnútropodnikovými cenami výkonov, ktoré vstupujú do ocenenia konkrétneho finálneho výkonu.

Každý z pohl'adov vedie $\mathrm{k}$ odlišnému zobrazeniu nákladov vo vzt’ahu k útvarom najmä $\mathrm{v}$ dvoch prípadoch:

- v prípade, ked' sa líši miesto vzniku a zodpovednost' za vznik skutočného prvotného nákladu,

- za predpokladu, že predmetom zobrazenia sú tzv. druhotné výkony, ktoré sú predmetom odovzdávania a preberania medzi útvarmi vo vnútri podnikovej štruktúry [2].

\section{Základné rysy sledovania režijných nákladov podl’a útvarov}

Zvláštný význam pre riadenie nákladov $\mathrm{v}$ nákladovom controllingu, primárne vo vzt'ahu k útvarom, má sledovanie najmä režijných nákladov. Potreba zachytit' režijné náklady pri ich členení podl'a miesta vzniku vzrastá najmä v prípade, pokial' ide o réžiu spoločnú viacerým druhom výkonov, ktoré sa v útvare vykonávajú. Pokial' by sme ich nezobrazili na vstupe (ked' ešte nie je celkom jasný vzt’ah k objemu a sortimentu vykonávaných výkonov) na útvarových účtoch réžie, v zásade by sme neboli schopní ani vyjadrit’ ich podiel na jednotku výkonu v prípade, ked’ $\mathrm{v}$ riadení vychádzame $\mathrm{z}$ akejkol’vek formy kalkulácie plných nákladov [2].

V zásade obdobným spôsobom, ale na usporiadacích účtoch ostatných priamych nákladov, je nevyhnutné zachytit' náklady, ktoré sú príčinne vyvolané jedným druhom vykonávaného výkonu.

Ešte väčší význam má však sledovanie útvarových režijných nákladov pri členení podl'a zodpovednosti za ich vznik. Réžie už svojou podstatou totiž predstavujú náklady, ktorých racionálnu kontrolu hospodárnosti je nutné založit' na úvahe, kto ovplyvňuje ich výšku, resp. kto zodpovedá za ich úsporu alebo prekročenie oproti vopred určenej nákladovej úlohe.

Túto úlohu možno v zásade stanovit’ dvojakým spôsobom [2]:

○ ako formou limitu spotreby, ktorý je vyjadrený na vymedzené časové obdobie (pri fixných režijných nákladoch), alebo

○ oproti úlohe, ktorá okrem časového interval berie do úvahy i objem aktivity, za ktorého priebeho priebeh útvar zodpovedá, tento spôsob sa používa ako nástroj stanovenia nákladovej úlohy pri variabilných režijných nákladoch.

\section{Záver}

Podnikatel', ktorý nekontroluje náklady svojho podniku, nepozná ich výšku a vývoj, vplyv na tržby, nepozná druhovú skladbu nákladov a celkovú nákladovú náročnost' na dosiahnutie ciel'ov podniku, nemôže byt' úspešný. Bez nákladového controllingu, analýzy a stáleho sledovania a porovnávania nákladov s výstupmi nejestvuje efektívny manažment.

Nákadový controlling tvorí jednu z najdôležitejších, ale aj najzložitejších fáz analýzy, čo manažment využíva tak pri kontrole plnenia plánu, ako aj v riadení podniku. 


\section{Literatúra}

[1] BOHUMIL KRÁL A KOL., Manažerské účetnictví, Management press, Praha, 2002, ISBN 80-7261-062-7

[2] FOLTÍNOVÁ A. A KOLEKTÍV.: Nákladový controlling, Sprint vfra, Bratislava, 2008, ISBN 978-80-89085-70-5

[3] TUMPACH MILOŠ.: Manažérske a nákladové účtovníctvo, Iura Eition, Bratislava, 2008, ISBN 978-80-8078-168-2

[4] KUPKOVIČ MILAN.: Náklady podniku, Sprint vfra, Bratislava, 1999, ISBN 80-8884850-4

[5] FOLTÍNOVÁ ALŽBETA, KALAFUTOVÁ LUUDMILA.: Vnútropodnikový controlling, Elita, Bratislava, 1998, ISBN 80-8044-054-9 